\title{
PRO-ECOLOGICAL ENERGY SOLUTIONS WHICH MINIMIZE THE USE OF FOSSIL FUELS IN THE ROOFED FACILITIES ${ }^{1}$
}

\author{
Sławomir Kurpaska \\ Institute of Agricultural Engineering and Informatics, University of Agriculture in Krakow \\ "Corresponding author: e-mail: rtkurpas@cyf-kr.edu.pl
}

\begin{tabular}{|c|c|}
\hline ARTICLE INFO & ABSTRACT \\
\hline $\begin{array}{l}\text { Article history: } \\
\text { Received: April } 2016 \\
\text { Received in the revised form: } \\
\text { June } 2016 \\
\text { Accepted: July } 2016 \\
\end{array}$ & \multirow{2}{*}{$\begin{array}{l}\text { The paper, based on the materials of the Main Statistical Office, } \\
\text { presents a present state of use of renewable energy sources in the } \\
\text { Polish power industry. Moreover, based on the available data, the } \\
\text { amount of energy used for roofed production was estimated (heat, } \\
\text { electric energy). Additionally, the amount of emission to atmosphere } \\
\text { of hazardous substances (sulphur oxides, lead oxides, carbon dioxide } \\
\text { and carbon oxide, dust and benzo(a) piren) was determined. Based on } \\
\text { the available literature, technical solutions, which are analysed in } \\
\text { various scientific centres, which aim at decrease of fuel consumption, } \\
\text { were presented. A detailed analysis focused on the possibility of } \\
\text { substituting fossil fuel with another heat source, effectiveness of } \\
\text { energy use, increase of insulation ability of the facility roof and modi- } \\
\text { fication of greenhouses structures. From among the available energy } \\
\text { sources, problems and its possible use in horticultural production were } \\
\text { presented. The following energy sources were analysed: geothermal } \\
\text { energy, sun and wind energy, biomass, heat pump; co-generative } \\
\text { system (triple co-generative). Also barriers and possibilities of use of } \\
\text { own boiler house and heat from central heating grid as energy source } \\
\text { were analysed. }\end{array}$} \\
\hline $\begin{array}{l}\text { Key words: } \\
\text { roofed facilities, } \\
\text { renewable energy, } \\
\text { pro-ecology technological } \\
\text { and structural solutions }\end{array}$ & \\
\hline
\end{tabular}

\section{Introduction}

An increasing number of people and requirements of healthy diet stimulate horticultural production development including one carried out under roofs. It is estimated that in 2030 the number of people on Earth will be from 7.5 to 10.5 billion (Cohen, 2002), and in Poland acc. to present demographical trends, the population will be approx. $37.2 \mathrm{mln}$ (Prognoza, on-line 2016). Existing legal regulations, care for environment, fear of fossil fuel resources depletion force EU countries, including Poland to reduce participation of conventional fuels in the energy balance of the country for the benefit of energy obtained from RES and improvement of energy effectiveness of processes. These requirements concern both heat and energy demand. The study (Gospodarka, on-line 2016) shows that Poland belongs to the biggest producers of primary energy in the European Union (8.9\% in 2013) and participa-

1 The study was financed from the subsidy of the Ministry of Science and Higher Education for statute activity 
tion in consumption is lower and amounts to $5.9 \%$ in 2013. In case of energy from renewable sources both in Poland and in the entire European Union, participation of this energy in the consumption of primary energy rises systematically. In recent years in Poland the increase of acquisition of renewable energy from biomass and wind was reported. On the other hand, the use of water and geothermal energy is not rising. According to the data of the Main Statistical Office (Gospodarka, on-line 2016) in 2014 participation of energy from RES in the final energy consumption was $11.45 \%$. Poland in 2014 produced 308 TJ from RES, however, by $2.4 \%$ less than in 2013 . This result was obtained mainly due to low reduction of the total energy consumption, which as a result of the assumed methodology caused increase of RES participation. In 2014 in Poland global energy consumption was approx. 4000 PJ (Gospodarka, on-line 2016) which constitutes almost 3.6\% of the total value. Figure 1 and 2 presents a percentage participation in agriculture of energy carrier in the consumed primary energy (Fig. 1) and energy which was formed as a result of fossil fuels processing. In total in agriculture at the end of 2014 primary energy consumption at the level of 61.4 PJ and energy processed in the amount of 81.2 PJ of energy was reported.

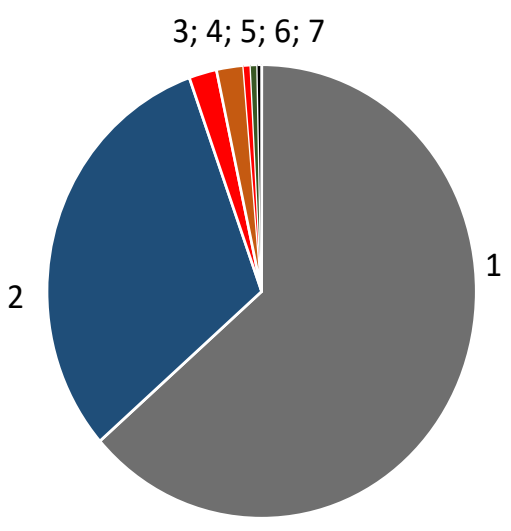

1- Hard coal $(63.56 \%)$

2- Peat and wood $(30.97 \%)$

3- Brown coal $(2.09 \%)$

4- Natural gas $(2.04 \%)$

5- Biogas $(0.53 \%)$

6- Nitrogen-rich gas $(0.51 \%)$

7- Waste fuel $(0.3 \%)$

Source: Author's own study based on: (Gospodarka, on-line 2016)

Figure 1. Structure of primary energy consumption in the Polish agriculture in 2014

Pursuant to the accepted legal regulations, Poland is obliged to obtain in 2020 at least $15 \%$ of energy production from RES in the total final energy consumption (2009/28/WE). According to the state of production at the end of 2015 there are serious threats that Poland entered the role of a candidate of purchase and must be aware that not later than in 2017 2020 it will have to incur considerable budget means for energy development from the energy market to fulfil its obligations.

According to the accepted economy purposes electric energy from RES in 2020 should constitute $25 \%$ of input in the general purpose. There are threats that this purpose on account of problems with water power energy (climatic reasons) and decrease of production of energy from biomass will not be achieved. Within the scope of heat generation from RES one may notice that for some time regress on the market is observed. In 2014 in comparison to 2013 heat production from RES dropped almost by 5.4\%. The main reason is in the deficiency of energy biomass for the dispersed heat engineering and its high price determined by professional electric energy is unacceptable for individual recipients. As 
Pro-ecological energy solutions...

a result of withdrawal of a subsidy in 2015 the market of solar panels was suddenly inhibited and the participation of energy from a heat pump recognized as RES is practically nonsignificant in the country's scale.

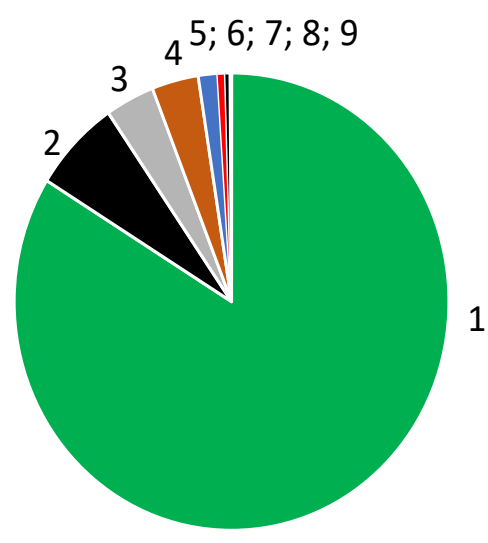

1- Diesel oil (83.87\%)

2- Electric energy (6.56\%)

3- Light oil $(3.65 \%)$

4- Liquid gas $(3.46 \%)$

5- Briquettes from brown coal (1.44\%)

6- Heavy oil $(0.57 \%)$

7- Coke and semi-coke $(0.34 \%)$

8- Non-energy products $(0.07 \%)$

9- Engine petrol $(0.04 \%)$

Source: Author's own study based on: (Gospodarka, on-line 2016)

Figure 2. Structure of consumption of processed energy in the Polish agriculture in 2014

Also, great problems occur with regard to biofuels and organic drives in the transport ( $20 \%$ participation was planned in 2020 in the RES consumption). Stagnation with a decreasing trend existing in the market has been observed since four years. There are presumptions to claim that since 2016 it will deepen. Since Poland did not modernize the sector of bioethanol production, thus it is energetically non-efficient and any modernizations were directed within the scope of biodiesel production from rapeseed, namely first generation fuels (according to the methodology they do not reduce more than $50 \% \mathrm{CO}_{2}$ net emission). Pursuant to the directive, provisions which will apply since 2017 considerably reduce the possibility of filling national aims with 1st generation biofuels. Presently, at the market there are no commercial technologies of second generation biofuels (e.g. from lignocellulose; also electric transport based on RES energy is not developed. Summing up, unfavourable tendencies which occur, may grow in the following years, without radical energy policy change. It may consequently lead to considerable burdening of the state budget because of the so-called statistical transfers on the $\mathrm{CO}_{2}$ market.

One should be aware that the existing programs and governmental strategies, which define state aims in the aspect of renewable energy sources use, create a space for their dynamic development in the following years. Presumptions for development of this energy consists in: reduction of energy costs, local safety of energy supplies, new workplaces on the local market, development of new technologies, positive impact on the natural environment and reduction of greenhouse gases emission.

In the light of the presented data, we should be aware that the increasing number of people in the world and a consumptive lifestyle are stimuli which cause development of horticultural production development including roofed production. Modern horticultural facilities are construed according to the accepted requirements (Critten and Bailey, 2002; Hare et al., 1984; Zwart, 1996) and should have, inter alia, rational heat consumption (with 
a possibility of its storing) adequate to (weather and equipment conditions) algorithms of control of microclimate parameters inside the facility and their high endurance and low exploitation costs.

The objective of the paper is a review of solutions in the structure and equipment of greenhouse facilities in the aspect of reduction of energy consumption together with suggested potential trends of development within the use of RES resources. In order to implement this intention firstly, one should estimate the energy demands of the production which is carried out.

According to the available data in Poland, horticultural production under the roof within the recent years has shown a rising trend. Table 1 presents data concerning the area of cultivation in Poland in 2014.

Table 1.

Area of horticultural crops in Poland in 2014 in roofed facilities (ha)

\begin{tabular}{lccccc}
\hline Specification & Tomatoes & Cucumbers & $\begin{array}{c}\text { Remaining } \\
\text { vegetables }\end{array}$ & Decorative plants & Total \\
\hline Greenhouses & 994 & 421 & 273 & 546 & 2234 \\
Foil tunnels & 1238 & 774 & 1560 & 533 & 4105 \\
Heated tunnels & 602 & 376 & 760 & - & 1738 \\
\hline
\end{tabular}

Source: Author's own study based on: Sppiopo, on-line 2016; Jabłońska and Olewnicki 2014

Based on the methodology (Kurpaska, 2008) and including temperature requirements for specific crops (Campiotti et al., 2016) it was calculated that the average heat demand for a greenhouse with tomatoes cultivation (facility with the $4 \mathrm{~m}$ high side walls, covered with single glass) will be $2050 \mathrm{MJ} \cdot \mathrm{m}^{-2}$. Using identical methodology, it was estimated that for the foil tunnel demand will be $900 \mathrm{MJ} \cdot \mathrm{m}^{-2}$. Including the presented data referred to the structure of cultivated plants (table 1) one may assume that the total heat demand in Poland will be: 45.8 PJ (greenhouses) and 15.6 PJ (foil tunnels). On the other hand, electric energy consumption (with assumption of the demand for unit electrical power in the height of $40 \mathrm{~W} \cdot \mathrm{m}^{-2}$ ) and existing structure of crops) is approx. $220 \mathrm{GWh}$ (production of vegetables) and $210 \mathrm{GWh}$ (decorative plants production). In calculations it was estimated that in case of production of vegetables (with the area of $1520 \mathrm{ha}$ ) only seedling will be additionally lighted ( 8 hours 45 days) and in case of decorative plants production (the area of 400 ha) lighting up will be carried out within a day for 10 hours within November to the end of the first decade of March.

If we assume that $95 \%$ of greenhouses in heated with carbon type coke breeze with calorific value of $19 \mathrm{MJ} \cdot \mathrm{kg}^{-1}$ and conversion of energy takes place in furnaces with the efficiency of 0.7 then the total mass of fuel consumed on production demand is almost 4.1 million tonnes.

Carbon combustion causes emission of hazardous substances to atmosphere. The applied calculations of emission (with reference to 1 tonne of the combusted fuel) and at the assumption of $1 \%$ of sulphur content prove that in relation to the furnace power and its structure particular emissions (expressed in $\mathrm{kg}^{\cdot \mathrm{t}^{-1}}$ ) are: $\mathrm{SO}_{\mathrm{x}} 16 ; \mathrm{NO}_{\mathrm{x}} 1 \div 3.2 ; \mathrm{CO} 10 \div 70 ; \mathrm{CO}_{2}$ $1850 \div 2130$; suspended dust $10 \div 20$; and Benzo (a) pyren 0.0032 $\div 0.014$ (Kobize, on-line- 
Pro-ecological energy solutions...

2016). Due to combustion, also costs of use of environment are incurred (Journal of Laws, of 2015, item 1875).

To conclude, one may state that heat generation leads to considerable pollution of environment and incurment of costs of use.

Thus, many research works which aim at the reduction of energy consumed on realization of the production process in roofed facilities and substituting mineral fuels with renewable energy.

\section{Pro-ecological solutions in roofed facilities}

Below, results of some research from the recent years were presented. These results cause reduction of fossil fuel consumption and as a result - also pollution of environment. Results of the research papers were discussed in several planes:

Replacement of fossil fuel with another heat source

Rooder et al., (2015) in his discussion on thermal economy based on biomass noticed that there is a strong relation of effectiveness of its use with reliability of supplies and transport distance. For two various scenarios of obtaining biomass they defined the incurred inputs on particular unit cycles in the aspect of biomass supply for production of electric energy. Bibbiani et al., (2016) determined possibilities of using bioenergy in Italian conditions for heating a greenhouse indicating the possibility of each time deep analysis on account of finances and organization. Hepbasli (2011) carried out exoergic analysis for three heating systems in a greenhouse: a hybrid system supported with a pump heat (bottom sources comprised a hot water heated in solar collectors), a boiler supplied with wood biomass and a gas furnace. Numerical values of exoergic coefficient were determined and as a result of analysis it was determined that the highest value is obtained for a hybrid case. Chau et al., (2009) carried out a technical and economical analysis of use (as an alternative for natural gas) of biomass in the form of pellets for heating a greenhouse. At the assumed period of exploitation, using the method of financial flows (NPV) they determined the effects including costs for elimination of dust which occurred in the biomass combustion process. Moreover, quantity effects in the form of reduced emission (in comparison to gas combustion) of carbon dioxide to atmosphere were defined. Thornley et al., (2015) analysed the solid biomass use during combustion in the aspect of greenhouse gases reduction and management of the recovered biocarbon from ash. Analysis was carried out for varied facilities which use fuel. The authors defined greenhouse gases emission for varied forms of biomass with the use of LCA method. Ozenger and Hepbasli (2005) researched the use of a heat pump (that cooperates with a vertical exchanger) for heating a greenhouse. The authors carried out exoergic analysis for the entire system and determined energy efficiency of the system. Laazar et al., (2015) analysed the use of solar energy (hot water heated in collectors) in the system, where heat was supplied with the use of membrane heat exchangers placed in the greenhouse floor and conduits placed inside it. They determined temperature inside the facility, a unitary heating efficiency of the investigated exchangers along with their energy efficiency and the period of return of incurred financial inputs. Attar and Farhat (2015) investigated a system in which hot water heated in solar collectors flew through an exchanger consisting of conduits located under the floor of a greenhouse. Costs of heating of the entire facility and relation of the surface of collectors to the cubic capacity 
of the heated greenhouse were determined. Usefulness of TRNSYS program for simulation of processes which take place in the investigated facility was proved. Aye et al., (2010) defined the effects (greenhouse gases emission, economic effects) for the system, in which a heat pump was used for heating a greenhouse and the peak load boiler was supplied with gas. Thermal effects were analysed with the use of TRNSYS simulation program. Russo et al., (2014) analysed the possibility of using a heat pump for heating a greenhouse supplied with PV system. A membrane exchanger, cooperating with geothermal boreholes constituted a bottom source. The authors carried out a comparative analysis in comparison to a greenhouse heated with a boiler supplied with LPG gas. They defined the period of return of investment costs and the environmental effects were estimated with the LCA methodology._Sonneveld et al., (2010) presented the research results in an experimental greenhouse, where a modified roof was installed, from which reflected beams were used in photovoltaic panels for production of electric energy. The authors estimated the effects of solar radiation conversion in heat and electric energy. Kurpaska et al., (2012), Kurpaska and Latała (2012a, 2012b) analysed the use of a heat pump cooperating with ground heat exchangers and operating in the hybrid system (bottom source comprised of hot water heated in solar collectors). In all combinations of an experiment the amount of obtained heat exceeded sometimes almost twofold of energy supplied for the system operation.

In the age of available technical solutions there is a possibility of installing as a source of heat and electric energy in the facility, co-generation systems (Skorek and Kalina, 2005). In this system, electric energy is generated directly, and the mixtures of oil, recovered from cooling the engine block used for cooling an engine and heat from cooling fumes is moved directly to the heating system for other purposes (e.g. heating water). With the use of a trigeneration system, not only economic indices of such a system are improved but additionally (on account of using natural gas/biogas devoid of sulphur) carbon dioxide indispensable in the plant production process is obtained.

\section{Effectiveness of energy use}

This concept includes both thermal management in a facility (ability to satisfy thermal needs at the minimal heat consumption) as well as the use of electric energy. Teitel et al., (1996a) investigated the impact of variable heating water temperature on the intensity of heat exchange in a greenhouse. They also determined a quantity cooperation of a mechanism of heat transfer to heating conduits to the surrounding air in the conditions of the nondetermined state (both at heating and cooling and during cooling heat transfer fluid). Kempes and Braak (2000) analysed parameters of microclimate inside a greenhouse (with cultivation of decorative plants), where varied heating systems (on account of location) were used. The authors found the relation of temperature around plants and change of air moisture to location of heating conduits. For the recommended location, they determined savings in heat consumption, reporting also that there are no differences in parameters which are responsible for amount and quality of yield. Teitel et al., (1996b) analysed two heating systems in a greenhouse: the system of heating with hot air (hot air was heated in a heater) and the system supplied with water heated in a heating boiler. Except for the difference in idleness of the heating system against enforcements, differences in micro-climate inside the facility were reported. Moreover, variability of heat in the non-determined process (to the moment of obtaining the intended temperature inside the facility): heat consumption by two systems was comparable. Hao et al., (2006) presented their results of temperature changes 
Pro-ecological energy solutions...

inside a laboratory greenhouse for two locations of the heating system. They found out that heating conduits located around plants, at the same technical and exploitation parameters of the system ensure higher temperature inside and around the plants. Within the scope of rational electric energy use the use of LED light sources for lighting is a noticeable trend. In literature there are many research papers that confirm that there is a possibility of such selection of a light wave length generated by monochromatic LED source and the light intensity that plant growth is comparable to lighting with high-pressure sodium lamps (Czynczyło-Mysza et al., 2007; Heo et al., 2002; Kim et al., 2004; Klamkowski et al., 2014; Pinho et al., 2007; Trouwborst et al., 2010). The non-published own research carried out as a part of the research project proved a possibility of obtaining such participation of particular LED waves length that more favourable distribution of spectrum in obtained (in comparison to HPS lamp) and consumption of electric energy per $100 \mathrm{~g}$ of lighted plant (corn salad) is over $100 \%$ higher. High investment costs are a barrier to extended recommendations of this source of light.

Increase of insulation of the facility roof

Research works focusing on alternative roofs for traditional garden glass aimed at meeting the required parameters of the roof material for a facility and included the analysis of: roof production costs, installation of thermal screens in a facility, impact of the usage period on the course of optical and physical properties of a roof, ensuring the maximum transmission of solar radiation to a roof (in particular within PAR light), increased, in comparison to glass, insulation properties, reduced possibility of settlement of dust which blocks the access of light, reduces formation of water drops on the inside of the cover during water steam condensation. Thus, Teitel et al., (2009) analysed air temperature change in a greenhouse with and without heat screens. They also determined temperature of leaves and they made the energy consumption dependent on the difference of temperature between a leave and air inside the facility. They also calculated the value of effective coefficient of heat penetration through the facility roof and they made it dependent on the wind speed. Fabrizio (2012) analysed heat consumption through the facility with the use of $0.1 \mathrm{~m}$ thick polycarbonate as its roof. It was found out that in comparison to the facility roofed with glass, savings in heat consumption are almost $30 \%$. In the research, also an innovative solar collector with regard to structure, which served for heating water, was applied. The change in the water amount in the buffer container into energy efficiency of the system was analysed. The standard of modern greenhouses is placing heating conduits around the plant roots. Cavins et al. (2000) recommend the use of floor heating in present greenhouses (placing heating conduits in the concrete isolated floor). Comparative research demonstrated that using this system means savings in heat demand of approximately $20 \%$ (in comparison to air heater). A recommended solution when heating facility under the roof is installing two boilers. One of them functions as a basic boiler and the second is started in the periods of maximum thermal load (Liao and Dexter, 2004).

The standard of equipment in modern roofed facilities (in particular in greenhouses) is installation of heat shields therein. Detailed data related to optic and thermal parameters regarding light issues and theoretical savings in heat demand may be found on the producer's webpage (Ludvigsvensson, on-line 2016). Exploitation research proved that in the Canadian climate conditions the use of heat shields in a greenhouse caused reduction of the total heat consumption at the level of $24-26 \%$ (Zhang et al., 1996). The research for the 
plastic tunnel (Kurpaska, 2003) prove that as a result of the use of heat shields and heater screens (a board with polyutherane with the width $1 \mathrm{~m}$ and thickness of $4 \mathrm{~mm}$ covered from the inside with the layer of aluminium foil) the maximum value of heat consumption reduction is almost $50 \%$. Grabarczyk (2010) reported that within the temperature difference between the inside of the facility and the surroundings savings in heat consumption are within 30 to $42 \%$. In the scientific centre in Poznan (Ogrodinfo, on-line 2016) together with partners from Norway and Holland a project is performed, in which one of the issue consists in the experimental research in a greenhouse, where two layers of PE plastic were used. In the space between them substance (soap foam) is periodically supplied thereto which aims at the reduction of heat loses. The operation cycle of the device which generated foam depends on the intensity and the angle of solar radiation. The research results prove that due to this method, in comparison to the control facility, heat consumption was reduced by almost $80 \%$.

\section{Control of microclimate inside the facility}

Abdel- Ghany et al., (2006) tested a laboratory method for determination of the temperature of glass used for the greenhouse roofing. Knowledge on it is indispensable for estimation of heat losses through radiation and thus during control of heating water parameters. The authors analysed the impact of temperature, solar radiation intensity and the wind speed, finding its higher usefulness in comparison to the method which uses NIR. The developed method was suggested also for measurement of temperature of other surfaces (PE foil, soil, plant leaves). Dehbi et al., (2010) in laboratory conditions analysed a temporary change of optic properties of foil used as a tunnel roof. They stated that air temperature inside and outside the facility influence the change of these parameters. Moreover, a negative impact of radiation within the length of UV waves was reported. Tantau and Lange (2003) developed an algorithm of control of the heating system and ventilation operation in a greenhouse with such parameters to exclude the danger of possible funghi diseases in a facility. The developed algorithm included the area of leaves of cultivated plants. The authors stating a dominance of this system over the traditional system (without parameters of plant growth), found the need of calibration adjusted each time to the species and size of plants as a drawback.

\section{A modified structure of greenhouses}

Joudi and Farhan (2014) analysed thermal parameters (dynamics of change of internal temperature, temporary heat demand) for the system which comprises a double roof constituting an air collector and a heat battery. For the varied amount of stream flowing through the collectors, the level of satisfaction of demand of the facility for the heat stored in a battery was determined. Ozenger and Ozenger (2010) investigated savings in heat consumption when a facility was heated during pressing of air sucked from the inside by conduits placed in the ground. Coefficient of energy performance of the system operation was calculated at the assumed speed of air through a membrane transducer and the temperature and moisture change in air inside the facility. Ghosal et al., (2004) Zhang et al., (2015) investigated thermal effects for the system where heat was stored in a soil battery located under the cultivation layer of a laboratory greenhouse. They determined air temperature change inside a facility during the battery operation and for the set internal temperature (for the facility with and without a battery) determined annual savings in energy consumption. 
Pro-ecological energy solutions...

The results of research work on storing in batteries of heat excess obtained from the inside of the tunnel were presented in Kurpaska et al., papers. (2015a, 2015b). Moreover, technical and exploitation guidelines were developed. It was concluded that storing of heat in a stone battery has positive effects (environmental, yield effects). There are many research papers concerning condensation drying of air in the literature (Han et al., 2015; Campen et al., 2002; Campen et al., 2003; Campen et al., 2009). The authors determined environmental effects, savings in heat consumption and suggested structural solutions for this system. In scientific centres in Holland (WUR Wageningen) and Canada (Ontario) there are ongoing works related to introduction of absorption drying to practice (salt water solution is used as absorber), The concept of the system operation consists in the removal of water steam from air (as a result of condensation or absorption). As a result, except for drying air, technological air has higher temperature. The results of the initial research demonstrate that there is a possibility of heat consumption reduction in comparison to a traditional heating system even up to $30 \%$ if the amount of ventilation air reduces with simultaneous rising of temperature.

The concept of a greenhouse with the absolute resignation of fossil fuel was presented in the paper by: Bot et al., (2005) and Ooster et al., (2007). The design assumes storing in summer the heat from the inside of a facility in water-bearing layers of soil (with the use of vertical heat exchangers) and its recovery (with the use of a heat pump) in winter. The authors assumed that micro-climate parameters will be maintained inside a greenhouse and calculated also the economic indexes of such a structure stating that at present prices of natural gas (as comparative fuel) this investment has no chances to succeed.

\section{Conclusion}

The studies carried out in numerous scientific centres assume minimization of heat consumption in roofed objects. A motivation for this research is reduction of operation costs, minimization of fossil fuels and consequently reduction of harmful substances emission to atmosphere. Satisfaction of energy demand may be achieved also with the use of renewable energy sources. Using available sources (geothermal energy, solar and wind energy, biomass, heat pump, co-generation system), one should be aware of potential problems. When someone decides to replace fossil fuel with an alternative source, the following should be taken into consideration: distance between the source and the heated facility, supply temperature, requirements concerning the return temperature, the content of salt, availability of the source, possibilities of supplying $\mathrm{CO}_{2}$ to the facility, costs of construction, usage permit, control at the stage of heat production, utilization of ash which was formed during the combustion process and pollution of environment (Kurpaska, 2007). Except for the mentioned problems, one should remember that the use of renewable energy sources with low temperature (geothermal water, heat pump, solar energy) implies considerable increase of the heating system surface. According to theoretical calculation at the average heating water temperature of $45^{\circ} \mathrm{C}$, almost threefold increase of the surface area of heaters is required in comparison to the standard temperature of supply which is $80^{\circ} \mathrm{C}$. Except for the increase of investment costs such a great heating surface will noticeably reduce light availability to the inside of the facility and as a result will cause reduction of the yield of cultivated crops. Thus, installation of a peak load boiler in such situations is fully justified. One should re- 
member that generally in the Polish agriculture the relation between the value of the obtained production and all incurred inputs in direct energy is weakly correlated (Pawlak, 2012). However, when some of the suggested solutions concerning energy savings, alternative energy sources are implemented, there are great chances to change this trend in the roofed production.

\section{References}

Abdel-Ghany, A.M., Ishigami, Y., Goto, E., Kozai, T. (2006). A Method for measuring Greenhouse Cover Temperature using a Thermocouple. Biosystems Engineering, Vol. 95(1), 99-109.

Attar, I., Farhat, A. (2015). Efficiency evaluation of a solar water heating system applied to the greenhouse climate. Solar Energy, Vol 119, 212-224.

Aye, L., Fuller, R.J., Canal, A. (2010) Evaluation of a heat pump system for greenhouse heating. International Journal of Thermal Sciences, VOL 49(1), 202-208.

Bibbiani, C., Fantozzi, F., Gargari, C., Campiotti, C.A., Schettini, E., Vox, G. (2016). Wood Biomass as Sustainable Energy for Greenhouses Heating in Italy. Agriculture and Agricultural Science Procedia, Vol. 8, 637-645.

Bot, G.P.A., van de Braak, N., Challa, H., Hemming, S., Rieswijk, T.H., van Straten, G., Verlodt, I. (2005). The solar greenhouse: state of the art in energy saving and sustainable energy supply. Acta Horticulturae, 691, 501-508.

Campiotti, C.A., Morosinotto, G., Puglisi, G., Schettini, C., Vox, G. (2016 ). Performance evaluation of a solar cooling plant applied for greenhouse thermal control. Agriculture and Agricultural Science Procedia, Vol. 8, 664-669

Campen, J. B., Bot, G. P. A. (2002). Dehumidification in Greenhouses by Condensation on Finned Pipes. Biosystems Engineering, 82(2), 177-185.

Campen, J. B., Bot, G. P. A., de Zwart, H.F. (2003). Dehumidification of Greenhouses at Northern Latitudes. Biosystems Engineering, 86(4), 487-493.

Campen, J.B., Kempkes, F.L.K., Bot, G.P.A. (2009). Mechanically controlled moisture removal from greenhouses. Biosystems Engineering, 102, 424-432.

Cavins, T.J., Dole, J.M., Stamback, V. (2000). Unheated and Minimally Heated Winter Greenhouse Production of Specialty Cut Flowers. Hort Technology, 10(4), 793-799.

Chau, J., Sowlati, T., Sokhansanj, S., Preto, F., Melin, S., Bi, X. (2009). Techno-economic analysis of wood biomass boilers for the greenhouse industry. Applied Energy, Vol. 86(3), 364-371.

Critten, D.L., Bailey, B.J (2002). A review of greenhouse engineering developments during the 1990s. Agricultural and Forest Meteorology, Vol. 112(1), 1-22.

Cohen, J.E. (2002). World population in 2050: assessing the projections.

Czynczyło-Mysza, I., Dubert, F., Marcińska, I., Kacińska, I. (2007). Influence of light emitting diodes (LED) on Vicia faba callus growth and differentiation. Zeszyty Problemowe Postępów Nauk Rolniczych, 523, 69-82.

Dehbi, A., Bouaza, A., Hamou, A., Youssef, B., Saiter, J.M. (2010). Artificial ageing of tri-layer polyethylene film used as greenhouse cover under the effect of the temperature and the UV-A simultaneously. Materials \& Design, Vol. 31(2), 864-869.

Fabrizio, E. (2012). Energy reduction measures in agricultural greenhouses heating: Envelope, systems and solar energy collection. Energy and Buildings, Vol. 53, 57-63.

Ghosal, M.K., Tiwari, G.N., Srivastava, N.S.L. (2004). Thermal modeling of a greenhouse with an integrated earth to air heat exchanger: an experimental validation. Energy and Buildings, 36, 219227.

Grabarczyk, S. (2010). Badania zmienności zużycia ciepła w szklarniach z osłonami energooszczędnymi. Czasopismo Techniczne, 4(107), 67-74. 
Pro-ecological energy solutions...

Han, J., Guo, H., Brad, R., Gao, Z., Waterer, D. (2015). Dehumidification requirement for a greenhouse located in a cold region. Applied Engineering in Agriculture Vol. 31(2), 291-300.

Hare, J.G., Norton, B., Probert, S.D. (1984). Design of greenhouses: Thermal aspects Applied Energy, Vol. 18(1), 49-82.

Heo J., Lee C., Chakrabarty D., Peak K., (2002). Growth responses of mariagold and salvia bedding plants as affected by monochromic or mixture radiation provided by a Light-Emitting-Diode (LED). Plant Growth Regulation, 38, 225-230.

Hepbasli, A. (2011). A comparative investigation of various greenhouse heating options using exergy analysis method. Applied Energy, Vol. 88(12), 4411-4423.

Jabłońska, L., Olewnicki (2014). Zmiany w powierzchni upraw ogrodniczych pod osłonami w Polsce w pierwszej dekadzie XXI w. Zeszyty Naukowe Szkoły Głównej Gospodarstwa Wiejskiego. Problemy Rolnictwa Światowego, Vol. 11(26), 89-97.

Joudi, K.A., Farhan, A.A. (2014). Greenhouse heating by solar air heaters on the roof. Renewable Energy, 72, 406-414.

Kempes, F.L.K., van de Braak, N.J. (2000). Heating system position and vertical microclimate distribution in chrysanthemum greenhouse. Agricultural and Forest Meteorology, Vol. 104(2), 133-142.

Kim, S.J., Hahn, E.J., Heo, J.W., Paek, K.Y. (2004). Effects of LEDs on net photosynthetic rate, growth and leaf stomata of chrysanthemum plantlets in vitro. Scientia Horticulturae, 101, 143-151.

Klamkowski, K., Treder, W., Wójcik, K., Puternicki, A., Lisak, E. (2014). Influence of supplementary lighting on growth and photosynthetic activity of tomato transplants. Infrastructure and Ecology of Rural Areas, IV/3, 1377-1385.

Kurpaska, S. (2003). Modyfikacja wyposażenia technicznego tunelu foliowego w aspekcie jego zapotrzebowania na ciepło. Problemy Inżynierii Rolniczej, 1, 39-46,

Kurpaska, S. (2007). Szklarnie i tunele foliowe: inżynieria i procesy. Poznań, Wydawnictwo PWRiL, ISBN:978-83-09-01024-1.

Kurpaska, S. (2008). Wymiary geometryczne oraz rodzaj pokrycia a zapotrzebowanie ciepła w szklarni. Inżynieria Rolnicza, 6(104), 89-96.

Kurpaska, S., Latała H., Łapczyńska-Kordon B., Mudryk K. (2012). Efficiency of the heat pump cooperating with various heat sources in monovalent and bivalent systems. TEKA. Commission of Motorization and Energetics in Agricultures, Vol 12(1), 109-113.

Kurpaska, S., Latała H. (2012a). Energy efficiency of ground heat exchangers cooperating with compressor heat pump. TEKA. Commission of Motorization and Energetics in Agricultures, Vol 12(1), 103-107.

Kurpaska, S., Latała H. (2012b). Analysis of the influence of variable insulating power of a storing tank on energy effects in the conversion system of solar radiation. TEKA. Commission of Motorization and Energetics in Agricultures, Vol 12(2), 293-301.

Kurpaska, Sł., Latała, H., Sporysz, M., Sikora, J., Mudryk, K., Konopacki, P., Hołownicki, R. (2015a). Some Aspects of the Analysis during Heating Plastic Tunnel by the Use of Heat from Stone Accumulator. Journal of Environmental Science and Engineering, 4, 154-160.

Kurpaska, S., Latała, H., Baran, D., Konopacki, P., Hołownicki, R. (2015b). Heat storing effectiveness with the use of a recuperator in the liquid type battery. Agricultural Engineering, 3(155), 47-57.

Laazar, M., Bouadila, S., Kooli, S., Farhat, A. (2015). Comparative study of conventional and solar heating systems under tunnel Tunisian greenhouses: Thermal performance and economic analysis. Solar Energy, Vol. 120, 620-635.

Liao, Z., Dexter, A. L. (2004): The potential for energy saving in heating systems through improving boiler controls. Energy and Buildings, 36, 261-271.

Ooster, van't A., Henten, van E.J., Janssen, E.G.O.N., Bot, G.P.A., Dekker, E. (2008) Development of Concepts for a Zero-Fossil-Energy Greenhouse. Acta Horticulturae, 801, 725-732. 
Ozenger, O., Hepbasli, A. (2005). Experimental performance analysis of a solar assisted groundsource heat pump greenhouse heating system. Energy and Buildings, Vol. 37(1), 101-110.

Ozenger, L., Ozenger, O. (2010). Energetic performance test of an underground air tunnel system for greenhouse heating. Energy, Vol. 35(10), 4079-4085.

Pawlak, J. (2012). Efektywność nakładów energii w rolnictwie polskim. Roczniki Nauk Rolniczych, Seria G, Tom 99, Z. 1, 121-128.

Pinho, P., Lukalla, R., Sarkka, L., Tetri, E., Tahvonen, R., Halonen, L. (2007). Evaluation of lettuce growth under multi-spectral-component supplemental solid state lighting in greenhouse environment. International Review of Electrical Engineering, Vol. 2(6), 854-860.

Rooder, M., Whittaker, C., Thornley, P. (2015). How certain are greenhouse gas reductions from bioenergy? Life cycle assessment and uncertainty analysis of wood pellet-to-electricity supply chains from forest residues. Biomass and Bioenergy, Vol. 79, 50-63.

Russo, G., Antifanis, A.S., Verdiani, G., Mugnozza, G.S. (2014). Environmental analysis of geothermal heat pump and LPG greenhouse heating systems. Biosystems Engineering, Vol. 127, 11-23.

Skorek, J., Kalina, J. (2005). Gazowe uktady kogeneracyjne, Warszawa, Wyd. Naukowo-Techniczne, ISBN:83-204-3103-4.

Sonneveld, P.J., Swinkels, G.L.A.M., Campen, J., Tuijl, van B.A.J., Janssen H.J.J., Bot, G.P.A. (2010). Performance results of a solar greenhouse combining electrical and thermal energy production. Biosystems Engineering, 106(1), 48-57.

Tantau, H-J., Lange, D. (2003). Greenhouse climate control: an approach for integrated pest management. Computers and Electronics in Agriculture, Vol. 40(1-3), 141-152.

Teitel, M., Shklyar, A., Segal, I., Barak, M. (1996a). A Comparison between Pipe and Air Heating Methods for Greenhouses. Journal of Agricultural Engineering Research, Vol.72(3), 259-279.

Teitel, M., Shklyar, A., Segal, I., Barak, M. (1996b). Effects of Nonsteady Hot-water Greenhouse Heating on Heat Transfer and Microclimate. Journal of Agricultural Engineering Research, Vol. 65(4), 297-304.

Teitel, M., Barak, M., Antler, A. (2009). Effect of cyclic heating and a thermal screen on the nocturnal heat loss and microclimate of a greenhouse. Biosystems Engineering, 102, 162-170.

Thornley, P., Gilbert, P., Shackley, S., Hammond, J. (2015). Maximizing the greenhouse gas reductions from biomass: The role of life cycle assessment. Biomass and Bioenergy, Vol. 81, 35-43.

Trouwborst, G., Oosterkamp, J., Hogewoning, S.W., Harbinson, J., van Ieperen, W. (2010). The responses of light interception, photosynthesis and fruit yield of cucumber to LED lighting within the canopy. Physiologia Plantarum, 138(3), 289-300.

Hao, X., Borhan, A.S., Zheng, J. (2006). Influence of Heating Pipe Placement on Microclimate of Greenhouses with Raised-Trough Tomato. Paper no. 064130, ASAE Annual Meeting.

Zhang, L., Xu P., Mao, J., Tang, X., Li, Z., Shi, J. (2015). A low cost seasonal solar soil heat storage system for greenhouse heating: Design and pilot study. Applied Energy, Vol. 156, 213-222.

Zhang, Y., Gauthier, L., Halleux, de D., Dansereau, B., Gosselin, A. (1996). Effect of covering materials on energy consumption and greenhouse microclimate. Agricultural and Forest Meteorology, 82(1-4), 227-244.

Zwart, de H.F. (1996). Analyzing energy saving options in greenhouse cultivation using simulation model. Ph.D. dissertation, Agricultural University of Wageningen.

Legal acts

Journal of Laws of 2005, item 1875 Resolution of the Council of /ministers of 12 October 2015 on the charges for the use of environment.

2009/28/EC Directive of the European Parliament and the Council of 23 April 2009 on promotion of renewable energy sources amending and repealing directives 2001/77/EC and 2003/30/EC.

Web pages

Prognoza (on-line 2016). GUS. Prognoza ludności polski na lata 2014 2050. Obtained from:

www.stat.gov.pl. 
Pro-ecological energy solutions...

Gospodarka(on-line 2016) GUS. Gospodarka paliwowa i energetyczna w latach 2013 i 2014r. Obtained from: www.stat.gov.pl

Kobize (on-line 2016) Krajowa baza o emisji gazów cieplarnianych i innych substancji. Obtained from: http://pl.wikipedia.org/wiki/Tarcie

Ludvigsvensson (on-line-2016) Dane dotyczące ekranów ciepła marki Svensson. Obtained from: www.ludvigsvensson.com

Ogrodinfo (on-line-2016) Portal ogrodniczy. Obtained from: www.ogrodinfo.pl

Sppiopo (on-line-2016), Stowarzyszenie producentów pomidorów i ogórków pod osłonami. Obtained from: www.sppiopo.pl

\section{PROEKOLOGICZNE ROZWIAZZANIA ENERGETYCZNE, MINIMALIZUJĄCE WYKORZYSTANIE PALIW KOPALNYCH W OBIEKTACH POD OSEONAMI}

Streszczenie. W pracy, w oparciu o materiały GUS, przedstawiono aktualny stan wykorzystania odnawialnych źródeł energii w polskiej energetyce. Opierając się również na ogólnodostępnych danych, oszacowano ilość energii wykorzystanej na potrzeby produkcji pod osłonami (ciepło, energia elektryczna). Określono także ilość emisji do atmosfery substancji szkodliwych (tlenki siarki, tlenki ołowiu, dwutlenek i tlenek węgla, pył oraz benzo(a)piren). Na bazie dostępnej literatury przedstawiono rozwiązania techniczne analizowane w różnych ośrodkach naukowych, mające na celu zmniejszenie zużycia paliw. Szczegółową analize skoncentrowano wokół: możliwości zastępowanie paliwa kopalnego innym źródłem ciepła, efektywności wykorzystania energii, zwiększenia izolacyjności osłony obiektu oraz modyfikacji konstrukcji obiektów szklarniowych. Spośród dostępnych źródeł energii odnawialnej przedstawiono problemy i potencjalne możliwości jej stosowania w produkcji ogrodniczej. Analizie poddano następujące źródła energii: energię geotermalną, energię słońca i wiatru, biomasę, pompę ciepła, układ kogeneracyjny (trójkogeneracjny). Analizie poddano również bariery i możliwości w wykorzystaniu jako źródło energii kotłownię własną oraz ciepło z sieci centralnego ogrzewania.

Słowa kluczowe: obiekty pod osłonami, energia odnawialna, proekologiczne rozwiązania technologiczno-konstrukcyjne 